\title{
Institutional and individual dimensions of transatlantic group work in network-based language teaching
}

\author{
JULIE A. BELZ \\ Department of Germanic and Slavic Languages and Literature, The Pennsylvania State \\ University, 311 Burrowes Building, University Park, PA 16802, USA \\ (e-mail: jab63@psu.edu)
}

\begin{abstract}
Network-based language teaching (NBLT) involves the application of global or local communication networks within foreign and second language education (Warschauer and Kern, 2000). In telecollaboration, a type of NBLT, distally located language learners use internet communication tools to support dialogue, debate, collaborative research and social interaction for the purposes of language development and cultural awareness (e.g. Kinginger et al., 1999). To date, the research on NBLT has been limited, focusing primarily on pedagogical implementations of technology and linguistic features of online communication. In particular, researchers have not robustly explored social and institutional dimensions of telecollaboration (Chapelle, 2000:217) nor have they adequately investigated the pervasive assumption that telecollaborative interaction will necessarily and unproblematically afford language learning (e.g. Kramsch and Thorne, to appear). Drawing on social realism (Layder, 1993), a sociological theory which emphasizes the inter-relationship between structure, i.e. society and institution, and agency, i.e. situated activity and psycho-biography, in researching and explaining social action, I present a sociocultural account of German-American telecollaboration. In particular, I explore the meanings that the macro features of (1) language valuation (Hilgendorf, 1996); (2) membership in electronic discourse communities (Gee, 1999); and (3) culturally determined classroom scripts (Hatch, 1992) may have for the differential functionality of virtual group work in this partnership. Differences in group functionality are reflected at the micro-interactional level in terms of (1) frequency and length of correspondence; (2) patterns of discursive behavior such as questionanswer pairs; and (3) opportunities for assisted L2 performance and negotiation of meaning. Ethnographic data (e.g. interviews, electronic and classroom discourse, surveys and participant observations) on individual psycho-biographies are interwoven with macro-level descriptions and statistics to paint a rich picture of learner behavior in intercultural telecollaboration. This project is funded by a United States Department of Education International Research and Studies Program Grant (CFDA No.: 84.017A). The author is a research associate for the German component.
\end{abstract}

\section{Introduction}

Network-Based Language Teaching (NBLT, see Warschauer and Kern, 2000) involves the application of communication networks in foreign language education. Telecollaboration is a type of NBLT which focuses on the use of globally-configured networks for the purposes of language learning and intercultural awareness (e.g. Kinginger, 
Gourvés-Hayward and Simpson, 1999; Warschauer, 1996a). Typically, learners communicate with members of the speech community under study using a variety of internet communication tools such as email and web browsers as well as video-conferencing.

Both researchers and practitioners have been enthusiastic about the ways in which NBLT may benefit language students and the relative pervasiveness that this type of learning may assume in the years to come. Tella (1996:7), for example, conjectures that "[i]nternational electronic keypals will be an automatic requirement for foreign language studies." Despite the enthusiasm for NBLT, research in this area has been limited (Kern and Warschauer, 2000:14). Studies have emphasized (1) pedagogical aspects of the integration of technology into language and culture curricula (e.g. Warschauer 1995); (2) linguistic features of online communication (e.g. Kern 1995); and (3) the motivational benefits of computer use (e.g. Warschauer 1996b). Researchers have not adequately investigated NBLT from a sociocultural perspective (Chapelle, 2000:217). In particular, they have not robustly examined the meanings that macro features of context and setting may have for (1) the development and functionality of telecollaborative partnerships; and (2) the pervasive assumption that telecollaboration will necessarily and unproblematically afford language learning and/or intercultural awareness (cf. Belz, to appear; Kramsch and Thorne, to appear; Warschauer, 1998:74-75).

The lack of emphasis on social and institutional dimensions of NBLT and learning appears to echo the mentalist focus in mainstream Second Language Acquisition (SLA) research where cognitive and linguistic factors are assumed to play a dominant and perhaps deterministic role in the acquisition of target language competencies (e.g. Firth and Wagner, 1997). More recently, however, sociocultural (e.g. Lantolf, 2000) and constructivist (e.g. McGroarty, 1998) approaches, which emphasize the role of socio-historically shaped learner agency in language development, have been attracting attention (e.g. Norton, 2000). In this paper, I wish to contribute to the corpus of NBLT research by presenting a sociocultural examination of a German-American telecollaborative partnership. Telecollaboration provides an ideal research site at which to explore sociocultural dimensions of language learning, since it necessarily involves linguistic, social, cultural and institutional contact. In particular, I examine the features of (1) language valuation; (2) access to technology; and (3) classroom scripts (Hatch, 1992:92) in conjunction with individual learners' situated agencies (see Pavlenko and Lantolf, 2000) in order to provide an explanatory frame for the differential development of internationally dispersed virtual group work within the larger networked class. Although studies on computer-supported international teamwork have begun to surface in the fields of organization theory and business education (e.g. Jarvenpaa, Knoll and Leidner, 1998; Klobas and Haddow, 2000), this learning format has been under-explored in the work to date on language learning in telecollaboration. I intend to show the meanings that social and institutional dimensions of a telecollaborative partnership may have for aspects of linguistic behavior on the micro-interactional level. These are: (1) the length and frequency of electronic communication; (2) particular interactional patterns; and (3) opportunities for peerassisted language development, negotiation of meaning, and intercultural awareness.

\section{Theory and method}

The theoretical and methodological tenets of social realism provide a framework for the 
analysis (e.g. Layder, 1993). Carter and Sealey (2000:5) present social realism as a theory of social action which emphasizes the inter-relationship between structure and agency. In the work of sociologist Derek Layder (1993), structure refers to macro sociological features of context such as gender, ethnicity and class, but also to more local features of setting such as institutional practices. Agency indicates the psycho-biographies of particular actors, i.e. the social experiences of the self over time, embedded in particular contexts and settings. Agency further encompasses emergent features of the more immediate situated activities (e.g. telecollaborative group work) in which those actors participate and interact.

Layder's (1993) theoretical emphasis on the inter-relationship between structure and agency is embodied in his research map (Layder, 1993:71-106), a methodological tool for the investigation of social reality which consists of four research elements: self, situated activity, setting and context. Carter and Sealey (2000:5) assert that "structured social relations provide the contextual conditions for social actions, and are a feature of social reality which extends beyond individual consciousness and control." At the same time, however, Carter and Sealey's conceptualization of social realism does not entail the reification of these structures and the subsequent social determination of individual participants' actions. Instead, these authors maintain that "it is only human beings who can have intentions, purposes and reflexivity: it is only human beings who can act in the world and are thus the 'agents' of social action." Each element of the research map crucially interfaces with the additional dimensions of history and power. Layder (1993:12) explains that history has a variable relationship to each of the elements in the map. For example, attitudinal changes of individual actors may be investigated over a relatively short time span, while processes of social evolution unfold over significantly longer time periods. To summarize, Layder's research map provides a concrete and detailed methodological tool which may extend the scope of NBLT research by generating exploratory questions about the meanings of social and institutional practices without neglecting the important role of individual psycho-biographies and interaction in the same process.

\section{Situated activity: German-American telecollaboration}

The networked class under study consists of sixteen English-speaking learners of German in a fourth-semester foreign language course at Penn State University (PSU) and twenty German-speaking learners of English in a Teacher Education Proseminar at the Justus-Liebig-Universität (JLU) in Gießen, Germany. ${ }^{1}$ The English learners in this Proseminar are preparing for careers as English teachers in German elementary and secondary schools. The class centers on language learning and intercultural awareness via the computer-mediated transatlantic negotiation of specific tasks that relate to a common engagement with parallel texts (e.g. Kinginger et al. 1999:858-60). Parallel texts are linguistically different renditions of a particular story or topic in which culturally-conditioned varying representations of that story or topic are presented. ${ }^{2}$ Students write equally in German and English. The German Proseminar meets once a week; the American language class meets four times per week.

${ }^{1}$ The JLU Proseminar was taught by A. Müller-Hartmann and the PSU language course was taught by the author. 
The networked partnership consists of four Phases. During Phase I (two months), when the German university is not in session, the American students publish a multimedia website which introduces themselves and their university community to their German keypals (Web Project I). At the outset of Phase II, the German students surf Web Project I and pick a partner based on perceived mutual interests. For the next four weeks, they discuss via email various topics which emerge from the parallel texts. In Phase III (three weeks), the German and American students form seven transatlantic groups which collaboratively design and publish websites (Web Project II). These sites contain (1) an essay relating to the parallel texts; and (2) the discussion of a cultural construct (e.g. 'racism', 'beauty') from multiple perspectives. The German students reflect on their telecollaborative experiences in Phase IV (two months).

The analysis presented here traces the development of differing group functionality from initial transatlantic dyadic/triadic communication in Phase II through virtual group work in Phase III to the completion of Web Project II, the assigned task for Phase III. There are three general American perceptions of electronically-mediated virtual group work in Phase III which do not uniformly echo the positive student orientations to NBLT and learning reported elsewhere (e.g. Warschauer, 1996b): (1) relatively equal American and German participation; (2) minimal German participation without direct transatlantic confrontation; and (3) minimal German participation with transatlantic confrontation.

\section{Virtual groupwork}

\subsection{High group functionality}

Group 4 represents one of two virtual groups that are characterized by high group functionality as evidenced by relatively equal German and American participation in the completion of Web Project II. Participation is demonstrated by frequency, length, mode, and content of transatlantic interaction. The group consists of two Americans, Suzanne and Joe, and three Germans, Gesa, Katrin, and Gabi.

\subsubsection{Phase II}

A structural and quantitative overview of the transatlantic electronic interaction in Phase II is given in Table 1. Suzanne and Gesa's emails are characterized quantitatively by frequent, lengthy exchanges. Semantically, their interaction is typified by personal narration. For instance, in her first email to Gesa, Suzanne writes: "My father was born in Germany and that's why I decided to study German. He doesn't remember much about Germany because he had to leave when he was only five. His family had to go because they were Jews" [email \#2]. ${ }^{3}$

Frequent consecutive questions are another hallmark of Gesa and Suzanne's electronic interaction, a pattern which may indicate high involvement and considerateness

\footnotetext{
2The juvenile novels Ben liebt Anna (1997) by Peter Härtling and If You Come Softly (1998) by Jacqueline Woodson form one set of parallel texts.

${ }^{3}$ All German language data are reported in English translation. Translations are my own.
} 


\begin{tabular}{|c|c|c|c|c|c|c|c|c|}
\hline 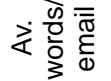 & $\begin{array}{l}\infty \\
\stackrel{m}{q}\end{array}$ & 㖞 & 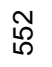 & $\widehat{\mathscr{Y}}$ & $\stackrel{\mathbb{N}}{N}$ & f & 占 & ळু \\
\hline $\begin{array}{l}\frac{10}{0} \\
\frac{0}{0}\end{array}$ & 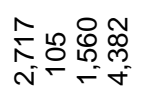 & 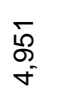 & $\begin{array}{l}\mathbb{1} \\
\infty \\
\infty \\
\infty\end{array}$ & 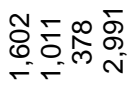 & $\begin{array}{l}\stackrel{J}{G} \\
\stackrel{-}{r}\end{array}$ & 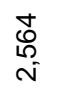 & Nis & $\begin{array}{l}\stackrel{U}{0} \\
\stackrel{N}{N}\end{array}$ \\
\hline 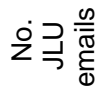 & n-ナ & $\sigma$ & $\wedge$ & $+\sim-\frac{\overrightarrow{5}}{5}$ & $\wedge$ & $\nabla$ & om $\frac{\vec{K}}{\circ}$ & g \\
\hline 它 & 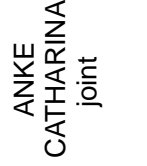 & 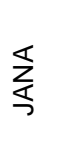 & $\begin{array}{l}\circlearrowleft 5 \\
\text { 山ु }\end{array}$ & 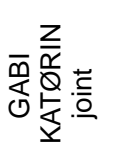 & $\frac{\text { 岁 }}{\sum_{<}}$ & $\begin{array}{l}\frac{\mathbb{5}}{\omega} \\
\frac{0}{\tilde{T}} \\
\frac{T}{0}\end{array}$ & 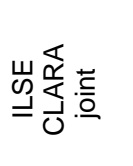 & $\begin{array}{l}\frac{0}{0} \\
\frac{0}{0} \\
0 \\
0 \\
0\end{array}$ \\
\hline 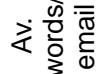 & 䒬 & 仓्లे & $\frac{0}{q}$ & 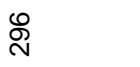 & $\stackrel{+}{N}$ & $\frac{m}{q}$ & $\stackrel{\mathscr{N}}{N}$ & ল্ল \\
\hline 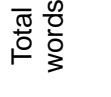 & : & 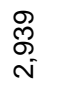 & $\begin{array}{l}\stackrel{L}{5} \\
\text { N } \\
\text { i }\end{array}$ & $\begin{array}{l}\text { i } \\
\text { i } \\
\text { a }\end{array}$ & 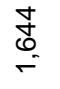 & 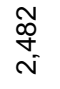 & \& & $\begin{array}{l}\dot{y} \\
\dot{0} \\
\dot{f}\end{array}$ \\
\hline 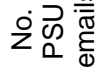 & 0 & $\infty$ & $\wedge$ & r & 0 & 0 & $\nabla$ & 寸 \\
\hline 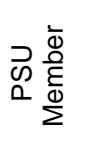 & $\frac{\mathcal{O}}{\tilde{W}}$ & 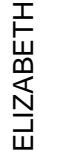 & 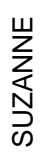 & 岁 & $\sum_{\text {离 }}^{\text {岀 }}$ & 豈 & ż & $\begin{array}{l}\frac{0}{0} \\
0 \\
0 \\
\\
\end{array}$ \\
\hline 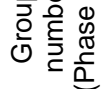 & $m$ & $m$ & $\sigma$ & $\sigma$ & 0 & 0 & 0 & \\
\hline 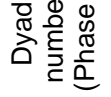 & 으 & $\mp$ & L & 0 & $\cong$ & $\stackrel{m}{\longrightarrow}$ & $\stackrel{\circ}{\circ}$ & 趁山 \\
\hline
\end{tabular}


(Tannen, 1981). For example, Gesa poses a lengthy series of questions which includes: "Is it difficult for people of different skin colors to get to know one another to be good friends?..." [email \#3]. Thematically, their questions are both text-related and personal. Their electronic communication is also marked by a high number of question-answer pairs. Unlike face-to-face conversation, asynchronous electronic question-answer pairs must necessarily span intervening time periods and are thus not chronologically adjacent (Good, 1977). To illustrate, Suzanne's response to Gesa's question about inter-racial relationships is given two days later: "In the United States, having an intercultural relationship is much more common than having an inter-racial relationship. People don't really think anything of mixing cultures since the USA is one big cultural melting pot; however, since interracial relationships are much more obvious on the surface, many people in the US tend to criticize them" [email \#4]. In many cases, their discussion of particular points extends over several electronic turns-at-talk (Sacks, Schegloff \& Jefferson, 1974). For example, in her next email Gesa incorporates Suzanne's information on inter-racial relationships and elaborates the virtual discussion of this topic from her perspective: "In contrast to the USA, I would say that we tend have more inter-cultural relationships here and therefore we engage with that..." [email \#5].

Joe has two German partners, Gabi and Katrin. Katrin corresponds infrequently. These students do not maintain discussion of a text-related topic for more than two electronic turns-at-talk. Instead, they volunteer personal information about their day-to-day activities and pose questions relating to these areas: "So, what did you dress up as [for Halloween]...YYou said that your weekend went too fast - I can only agree with that...[I] met some friends, went to a Bach concert, had to watch a video for my Didactics class..." [email \#5]. A persistent theme in Joe's correspondence is his low proficiency level in German: "I have to say that I feel a little bit childish because your English is better than my German" [email \#2]. In response to this 'confession', Gabi attempts to attend to Joe's positive face, i.e. his desire to be appreciated, respected, and liked by others (Brown and Levinson, 1987): "I think it's great that you're even studying a foreign language and I don't find your abilities to be childish at all..." [email \#3].

Table 2. Phase III correspondence

\begin{tabular}{|c|c|c|c|c|c|c|c|}
\hline Group & $\begin{array}{c}\text { PSU } \\
\text { members }\end{array}$ & $\begin{array}{l}\text { JLU } \\
\text { members }\end{array}$ & $\begin{array}{l}\text { Total } \\
\text { emails }\end{array}$ & $\begin{array}{l}\text { PSU } \\
\text { emails }\end{array}$ & $\begin{array}{l}\text { JLU } \\
\text { emails }\end{array}$ & Chats & Phone calls \\
\hline 3 & $\begin{array}{c}\text { ERIC } \\
\text { ELIZABETH }\end{array}$ & $\begin{array}{l}\text { ANKE } \\
\text { CATHARINA } \\
\text { JANA }\end{array}$ & 20 & 10 & $\begin{array}{l}10 \\
\text { EL\&J } \\
\text { only }\end{array}$ & 2 & $\begin{array}{c}\text { ELIZABETH/JANA: } \\
1\end{array}$ \\
\hline 4 & $\begin{array}{l}\text { SUZANNE } \\
\text { JOE }\end{array}$ & $\begin{array}{c}\text { GESA } \\
\text { KATØRIN } \\
\text { GABI }\end{array}$ & 32 & 9 & $23^{*}$ & 5 & $\begin{array}{c}\text { JOE/GABI: ca. } 5 \\
\text { SUZANNE/GESA:1 }\end{array}$ \\
\hline 6 & $\begin{array}{l}\text { DON } \\
\text { JENNIFER } \\
\text { BETH }\end{array}$ & $\begin{array}{c}\text { ILSE } \\
\text { CLARA } \\
\text { ANNIKE } \\
\text { CHRISTA }\end{array}$ & 12 & 7 & $5^{\dagger}$ & 0 & none \\
\hline
\end{tabular}

* Eight of the JLU emails are uploaded images. Three of the JLU messages are short goodbye messages. †Two of the JLU emails are short goodbye messages. A third email which contains the German contribution to the cultural construct was posted after the American semester ended. 


\subsubsection{Phase III}

A quantitative and structural overview of Phase III is given in Table 2. The frequency of correspondence and the diverse modes of tele-communication among most of the members of Group 4 in Phase III stand out. In synchronous chat, the members of this group discuss the difference between German and American orientations to time, mobility and communication style based on excerpts from Hall and Hall (1990). The heavy reliance of this group on chat as a means of telecollaboration in internationally dispersed virtual group work appears to foster opportunities for both other and self-initiated peer-assisted L2 performance with respect to lexical, syntactic, pragmatic, and cultural competency. In the following representative excerpt, Joe, Suzanne and Gesa are discussing the description of personal relationships in Hall and Hall (1990):

1. GESA: what do you two think about the superficial relationships? is that true?

2. SUZANNE: nein (no)

3. SUZANNE: es gibt ein wort 'acquaintances' (there is a word 'acquaintances')

4. SUZANNE: kennst du das? (do you know that?)

5. GESA: ja (yes)

6. GESA: es heisst auf Deutsch 'Bekannte' (in German it's called 'Bekannte')

7. SUZANNE: ok

8. GESA: ungefähr (approximately)

9. JOE: Es gibt ein Verschied zwischen 'Bekannte' und 'Freunde' (there is a difference between acquaintances and friends)

10. SUZANNE: Meine Bekannte sind nicht meine gute Freunde (my acquaintances are not my good friends)

11. GESA: ja (yes)

12. JOE: Gwen, could you clear something up for me...

13. GESA: sure

14. JOE: how do you differentiate if you're talking about a female friend or a girlfriend?

15. JOE: they are both 'Freundin'

16. JOE: nicht? (aren't they)

17. GESA: yes

18. SUZANNE: Die Beziehungen, die ich mit meinen guten Freunden haben sind tief (the relationships that I have with my good friends are deep)

19. GESA: there is no real way to differentiate, not like in English

20. SUZANNE: und ich finde, dass viele Amerikanische Leute zustimmen wurden (and I find that many Americans would agree)

21. JOE: for female friend would you say 'Eine Freundin von mir' ? (a friend of mine)

22. JOE: and for girlfriend 'Meine Freundin' (my [girl]friend)

23. GESA: I just started to type the same thing [chat session, December 4, 2000]

In line 3 Suzanne introduces the English word 'acquaintance' in order to begin discussion of the assertion in Hall and Hall (1990) that Americans tend to have more 
superficial personal relationships than Germans. Gesa provides lexical assistance in line 6 by supplying the German word Bekannte. In line 10 Suzanne uses this lexeme as she begins her commentary on this point. In lines 14 and 16 Joe takes this opportunity to request assistance in the same semantic field with regard to distinguishing between 'female friend' and 'girlfriend' in German. In lines 21-22 he checks his classroom learning of these items against the opinion of a native speaker. In other instances of synchronous chat, the members of Group 4 spend a significant amount of time in meta-linguistic discussions of textual organization for their collaborative essay.

\subsection{Low group functionality}

Group 6 is one of four groups which the American learners perceive to be characterized by minimal German participation in the completion of Web Project II: “...I learned that our German counterparts were irresponsible and had a 'no care' attitude about the project in general. As a result, we did end up doing most of the work." [Beth, course evaluation] The other American members of Group 6 are Don and Jennifer; the German members are Ilse, Clara, Annike, and Christa.

\subsubsection{Phase II}

The American members of this group have some of the lowest overall quantitative participation levels (see Table 1). Don, for example, ranks last at 943 in terms of total words written. His electronic correspondence is characterized by a lack of both text-related and personal questions. Clara, by way of contrast, asks Don many questions. The following one, for example, is located in a series of ten consecutive questions about Woodson (1998): "What I would like to know is, is it really so bad for a Black person to run in Central Park?" [email \#3]. Don does not answer Clara's questions. His lack of response regarding racism and Central Park is particularly salient, since Don grew up in New York City and has a negative attitude toward city life [web-biography]. Clara directly addresses Don 's lack of involvement in her next mail. Don has a negative evaluation of the American students' linguistic abilities in general. He confides in the author that he thinks the Germans' English might be better than the Americans' English, since the Germans are studying to be English teachers [personal communication, September 2000].

Jennifer receives the fewest total written words $(1,644)$ from her German partner, Annike, who also has the lowest average number of words per email at 235 . These data are noteworthy in light of Annike's relatively enthusiastic pre-semester course expectations: "...it is very interesting to communicate with students abroad and I like to talk about movies and literature... [I want] to get to know some people in the United States [and] to write e-mails and to talk" [biographical survey]. Thematically, however, Jennifer and Annike's emails are superficial. In email \#3, Annike reports: "For today we had to read Ben liebt Anna. I think you have to read it too. What do you think about the story? I liked it." In email \#4, Jennifer continues the discussion of the juvenile novel: "What do you think about interracial relationships? Here, it isn't a big deal to most people in my generation, but sometimes parents object to it...I think that in the case of Ben liebt Anna when a couple are from different cultures that can even make a relationship more interesting." Annike does not respond to this. In email \#5, Jennifer moves on 
to the Disney adaptation of the German Cinderella story: "Do you ever have American stories changed to reflect German values?" In her 149-word response in email \#6, Annike writes: "Yesterday I read Aschenputtel in the German Version. I think it has an very happy ending and I'm so glad that Aschenputtel marrys the prince." In email \#7, Annike adds the following comment to the Cinderella discussion: "I have enough fantasy and I don't like to talk about deeper senses of such happy movies." In an interview, Jennifer relates that she feels disappointed during Phase II because she "never got anything back" from her partner.

Beth receives the fewest number of total emails from her German partner, Christa; however, Christa's correspondence displays the highest number of average words per email at 641. These partners offer personal information, ask both text-related and personal questions, and regularly answer each other's questions. Their discussion of racism, prompted by Woodson (1998), extends over five emails touching on both National Socialism and the KKK. In an interview, Beth relates that she was "really pleased" with her interaction with Christa.

\subsubsection{Phase III}

The German collaborators in Group 6 contribute three emails to the negotiation and production of Web Project II. The American students express strong negative reactions regarding both the frequency and content of German participation: “...it was like insulting what they sent us compared to what we sent them" [Jennifer, interview]. However, they do not explicitly tell their German partners about their dissatisfaction; instead, they complain to the instructor. In the end, two of the German members in Group 6 send another contribution to the cultural construct assignment, but it reaches the American group after the end of their semester. Jennifer does not appear to appreciate this contribution: “...I was really pissed because they sent an email like the Tuesday after it was due."

\subsection{Low group functionality with direct confrontation}

Group 3 is also characterized by the American perception that there is minimal German participation in the negotiation and completion of Web Project II. The difference between Groups 6 and 3 is that there are explicit episodes of meta-commentary on group functionality from the German side of the group in the electronic interaction during Phase III. The American members of Group 3 are Eric and Elizabeth; the German members are Anke, Catharina, and Jana.

\subsubsection{Phase II}

Eric corresponds with Anke and Catharina in Phase II. Quantitatively, Eric's participation ranks second lowest for the Americans in terms of total words written and average words per email (see Table 1). By way of contrast, Eric receives the most emails from his German partners and the second highest total number of words written. Anke writes the single longest email of any German at 1,271 words, a majority of it in English. She provides detailed information about herself and explains that such an exchange will 
facilitate discussion of the parallel texts because she doesn't want to "tell kinda 'strangers' [her] feelings, even if it is only about a book..." [email \#4]. Eric does not respond in kind nor does he follow-up on Anke 's suggestion that they correspond outside of class time. He does answer some of Anke and Catharina's questions, but his replies remain brief. Anke and Catharina tell Eric that they do not like the way he is participating in the partnership: “...we think it is sad that you only write us about the things the teachers tells you to. Are you interested in us or only on your mark you will receive at the end of the year?" [email \#14]. Eric does not write to Anke and Catharina again.

Quantitatively, Jana has the highest number of total words written for the Germans as does Elizabeth for the Americans. Their correspondence is characterized by personal narration and both text-related and personal questions. In her web-biography, Elizabeth writes that she knows almost nothing about German culture and that she would like to learn more during the partnership. When Jana relates in her first email that her boyfriend lives with her at her parents' house, Elizabeth 's desire for cultural learning is met in an unexpected way. She is so surprised by this 'revelation' that she clarifies her understanding of Jana 's German with the author [personal communication, October, 2000]. Jana and Elizabeth 's extended discussion of this topic over four electronic turns-at-talk is typical of their interaction. Negotiations of and apologies for misunderstandings also span multiple emails. Jana and Elizabeth write to one another outside of class time and are meticulous about answering one another's questions. To illustrate, Elizabeth writes: "I took [this email] home with me to finish...I am going to try and answer all of your questions that you asked..." [email \#8]. Finally, Jana and Elizabeth explicitly show enthusiasm for the partnership and appreciation for one another's correspondence. For example, Elizabeth tells Jana “I thought your Email was wonderful!" [email \#8].

\subsubsection{Phase III}

At the outset of this Phase, Eric and Elizabeth propose a tentative outline for the collaborative essay. For the cultural construct they suggest that each national group describes the typical German and the typical American. Anke and Catharina do not appear to conceptualize negotiation as a key step in these assignments, since they work on the project in isolation from the rest of the group. Jana is unhappy with their participation: "For me, it wasn't really group work, like I had wished for. There were no discussions about the topic and no exchange of opinions concerning the individual points" [project evaluation]. Jana and Elizabeth, however, continue their pattern of heavy transatlantic participation (see Table 2).

Further, Anke and Catharina do not seem to conceptualize themselves as language learners in Phase III, because they decide to write their segments of the project in their L1 and tell Elizabeth and Eric to do the same [email \#15]. Elizabeth clearly sees herself as a language learner when she complains to the author about this arrangement, stating that it "kinda defeats the purpose" [personal communication, November, 2000].

At this stage, Anke and Catharina explicitly complain to their American partners about two aspects of their partnership: (1) Eric and Elizabeth's revisions to the essay outline; and (2) the content of Elizabeth's cultural construct. In the first instance, they comment: "We are not very impressed with your work! It is not possible to give us an outline to work on and then suddenly change it after a week... We think you don't do any 
partner work with Germany at all" (emphasis added). In the second case, they remark: "We hope, Elizabeth and Eric, that you got a more realistic way of thinking about Germany, cause your thoughts are so political correct that such a country cannot exist at all. We are just human and not a perfect race."

In sum: Highly functional Phase III groups tend to progress from highly functional Phase II dyads/triads. Discursively, these dyads/triads are characterized by (1) lengthy and/or frequent electronic correspondence; (2) 'machine gun questions' (Tannen, 1981); (3) asynchronous question-answer pairs; and (4) thematic discussions which span multiple electronic turns-at-talk.

\section{Language valuation}

English and German are valued differently in German and American society, respectively. This fact is portrayed vividly by national trends in foreign language education. The US National Center for Education Statistics (NCES) reports that 326,000 or 2.7\% of all secondary school children in grades 9-12 are enrolled in German courses in 1994. In contrast, the German Statistisches Bundesamt or the Federal Statistical Office reports that $97.3 \%$ of all children in the 5th grade and $99.8 \%$ of all children in the 7th grade receive instruction in English in 1998. In 1997 German president Roman Herzog (1997:9) suggests in the Frankfurter Allgemine Zeitung that English instruction begin even earlier in German schools: "[W]arum beginning wir nicht mit dem Englischunterricht in der Grundschule?" 'Why don't we give English instruction in elementary school?'

Knowledge of English is seen by many Germans as advantageous for career opportunities, particularly in the business world: "Ohne Englisch hat man in Zeiten der Globalisierung keine Überlebenschancen." 'In the age of globalization one has no chance of survival without knowledge of English' (Leiter, in Reichert, 2000:33). The English language also permeates present-day German pop culture and advertising. For example, Weber (2000:246) portrays the pervasiveness of English in the German Alltag in the following way:

"Schon kurz nach dem Aufstehen beginnt der Sprachenkampf...Auf dem Weg zur Arbeit fällt einem aus dem BMW-Showroom wieder mal das Plakat mit der Aufschrift 'Protected Drive' in die Augen...noch schnell in die Post, einen Auslandsbrief aufgeben. 'Premium oder Economy', lautet die selbstverständliche Frage des Schalterbeamten. Und dann wird, im Office, den lieben langen Tag designt und gecancelt, gelayouted und downgeloaded und mit Genehmigung des neuen Duden sogar gehighlighted."

"The war of the languages begins shortly after getting up...Once again on the way to work the poster with the slogan 'protected drive' jumps out at me from the BMW showroom... a quick stop at the post office to mail an overseas letter. 'Premium or economy' comes the matter-of-fact question of the postal worker. And then at the office, the whole day long, we 'design' and 'cancel', we 'layout' and 'download' and, with the approval of the new Duden, we even 'highlight'." 
German, by way of contrast, does not have similar currency in American education, business, pop culture or advertising. This differential social valuation and subsequent instruction in and exposure to English and German in Germany and the US, respectively, may afford a mismatch in transatlantic student proficiency levels, if classes are paired in terms of age and/or educational levels. For student participants, proficiency may be less readily discernible in the electronic medium than in face-to-face conversation due to (1) the lack of particular communicative signals such as pronunciation; and (2) the opportunity for revision afforded by both the written nature and the asynchronicity of some types of Computer-Mediated Communication (CMC). It is precisely these features of CMC that some researchers have called its greatest affordances to learning (e.g. Sproull and Kiesler, 1991); in some cases of German-American telecollaboration, however, they may function as constraints.

Don is a case in point. He rates as an Intermediate Low in a pre-semester oral proficiency interview (OPI; administered by the American Council on the Teaching of Foreign Languages [ACTFL]). ${ }^{4}$ Nevertheless, Ilse and Clara are positively impressed with his German abilities as evidenced in his web-biography: "Your German really sounds perfect" [email \#1]. What they may not adequately consider is that this hypertext is the result of an 8-week student-teacher collaborative effort. The 50-minute in-class situated activity of email correspondence may afford Don a very different L2 performance. Don 's brief emails, therefore, may be related to his proficiency level. His suggestions in emails \#4 and \#7 that he and his partners write to one another outside of class time may be an attempt to move the activity of German email correspondence into a context which will afford him greater opportunities to demonstrate positive face. But Clara appears to have interpreted Don 's brief and infrequent emails pragmatically as a threat to her positive face, rather than grammatically as a marker of his lower proficiency: "I find it rather sad you answer that rare to our mails...Was there anything in our mails that you didn't like?" [email \#6]. Ilse notes in her project evaluation that she and Clara do not take Don up on his offer to write outside of class. Her pragmatically-oriented perceptions of Don 's emails may preclude this development: "I have to say that we were somewhat disappointed about our American partner...Since we were happy if our partner wrote us once a week we saw no point in writing to him twice a week" [project evaluation].

A similar development may have taken place in the case of Eric and Anke/Catharina. Each student's characterization of the parallel texts indicates a mismatch in proficiency levels. Anke and Catharina refer to Woodson (1998) as "extremely easy to read", while Eric describes Härtling (1997) as "difficult" and remarks that he had to look up many words in the dictionary. When Eric writes "Wow! that was a really long letter..." in response to Anke's 1,217-word email, he may be reacting not so much to the length of her email per se as he is to her ability to produce so much in English. The fact that he does not exchange the same information with her may have more to do with ability than desire. Anke and Catharina seem to indicate that differential language proficiency is a problem when they write in their project evaluation that "equal proficiency levels on both sides" should be a prerequisite for participation. Nevertheless, they seem to connect Eric's brief electronic contributions more to pragmatic issues than to grammatical

${ }^{4}$ Thanks to Antonio Jimenez for the coordination of OPI testing. 
ones: "People who are not really interested in Germany/USA or who are afraid to tell something about their lives should not be allowed to participate" [project evaluation].

\section{Technological access and use}

The difference between Germany and the US with respect to technological access and use is less pronounced on the societal level of context than on the institutional level of setting. The Statistisches Bundesamt reports that $47 \%$ of German households owns a personal computer in 2000, while the US National Telecommunications and Information Administration (NTIA) states that $51 \%$ of all US households owns a computer in the same year. The same sources record that $17.4 \%$ of German households in the former West German states has internet access in 2000, while $41.5 \%$ of all US households has internet access in the same year. Penn State University, however, is rated as the 12th most wired university in the US in 2000 (Bernstein, Caplan \& Glover, 2000). 30,000 undergraduate students have (1) 14,065 free-of-charge student residence hall Ethernet connections; (2) 115,000 free-of-charge student/staff/faculty email accounts; and (3) 4,372 computers in open-access student computing labs (Kerlin, 2001). In contrast, the 20,000 students at JLU have access to approximately 250 computers in university computing labs (Müller-Hartmann, personal communication, March 2001). Limited hours of operation constrain access and thus virtual group work as seen in the following chat session excerpt:

SUZANNE: you can say all the examples that prove our thesis and give one or two reasons why this might not be the case

GABI: ich werde in 15 min rausgeschmissen (I will be kicked out in 15 minutes)...

GESA: wie lange hat die UB [Universitätsbibliothek] auf?... (How long is the library open?)

JOE: bedeutet rausgeschmissen 'kicked out'? (does rausgeschmissen mean kicked out?)

GESA: $j a$ (yes)

JOE: damn, I was hoping to finish this part

GABI: bis 6 aber die Computer nur bis 17.15 (until 6 but the computers only until 5:15 p.m.)

[chat session, December 2, 2000]

In general, it appears that computer-mediated activities are more integral to the lives of the PSU students in this study than to the JLU students (see Table 3). For example, 50\% of the PSU students has a personal homepage, while no JLU students do. The PSU average daily computer usage is three times greater than the JLU daily usage. To personalize these data, consider Anke and Catharina who both have free email accounts through hotmail.com, but pay $\$ 5.00 /$ hour at an internet café in order to access them [project evaluation]. In other words, the PSU students in this study are more likely to be members of Electronic Discourse Communities (EDCs) than the JLU students are. Educational researcher James Gee (1999:38) refers to discourse communities as "ways of performing and recognizing characteristic identities and activities."

The PSU students may bring their out-of-class expertise as members of EDCs to bear 


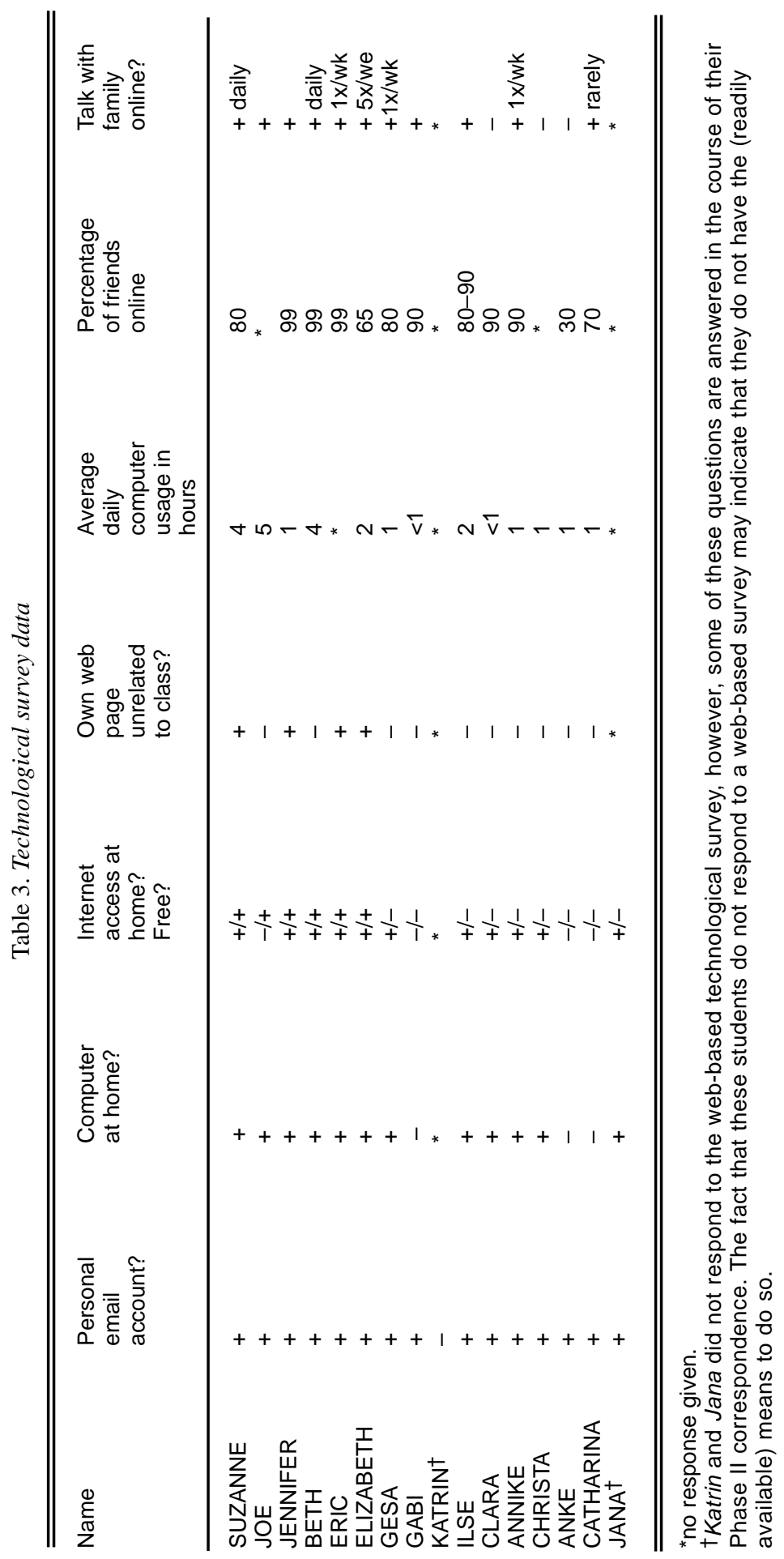


on the in-class use of technology in Foreign Language Learning (FLL) in ways that the JLU students do not. For example, telecollaborative FLL may be conceptualized as "just German with computers" [Joe, interview] by students who are regular participants in EDCs (see Table 3), but as a chance to learn about working with the computer and "all its deceitfulness" [Anke and Catharina, project evaluation] by students who are not (see Warschauer 2000:49). Some JLU students may conceptualize the telecollaborative partnership as using computers to 'obtain facts' (see later) about US language and culture, whereas some PSU students might view the telecollaborative partnership as an expansion of their already prolific electronically-mediated activities to include German (e.g, Shetzer and Warschauer, 2000:172).

Anke and Catharina reveal themselves, at best, as peripheral members in EDCs when they comment that one of the main things they learned is that virtual group work is difficult "without internet access" [project evaluation]. Their peripheral membership may explain their surprise/outrage when they discover that their partners have changed the project outline in the intervening week since they last sat before the computer in class. In short, they may be unfamiliar with the potential for rapid interaction and the pervasive modification of text in the electronic medium. Their sometimes violent reactions to Elizabeth and Eric's mode of participation in virtual group work may indicate that they interpret their American partners' frequent postings and revisions pragmatically as uncooperative, individualistic acts in the group-oriented context of Teamarbeit, instead of as typical ways of performing identity and activities in electronic discourse communities. By the same token, as more prototypical members of EDCs, Eric and Elizabeth may have few resources with which to interpret their German partners' reactions to what for them are normal patterns of interaction in the electronic medium. Similarly, Annike's quantitatively brief and semantically superficial emails take on new meaning when one considers that she might have written "much longer and in more detail", if internet access had not been so expensive [project evaluation].

\section{Institutionalized classroom scripts}

Hatch (1992:85) refers to a script as "the knowledge that people have of the structure of stereotypic event sequences such as grocery shopping." Schank and Abelson (1977) suggest that scripts consist of (1) actors who have (2) specific goals; (3) event sequences; (4) and props. As Hatch (1992:89) notes, scripts are culture-specific and may need to be "radically amended" if one comes in contact with a different speech community or uses a different language.

The typical US university-level classroom script involves students (actors) who participate in courses in order to fulfill degree requirements so that they can graduate and secure jobs (goals). Graduates who have the best Grade Point Averages (GPAs) have the best chances for the best jobs. GPAs are calculated as the average of all individual grades students receive in individual courses over the duration of their degree programs. If students' GPAs sink below a certain level, they may be forced per university regulations to discontinue their studies. Therefore, getting a good grade is one of the primary goals of actors in the US classroom script.

Learning is conceptualized typically as the passive receipt of facts and figures transmitted by the teacher to the student (e.g. Cortazzi and Jin, 1999; Pavlenko and Lantolf 
2000; Reddy, 1993). Grades are assigned on the basis of demonstrated learning. Thus, an important scene within the classroom script is learning evaluation. In the US classroom script, there are frequent, low-stakes learning evaluation scenes such as quizzes and homework. In order to get good grades, American students typically invest a great deal of time in the completion of evaluation scenes.

In German society, good grades are also important for future employment opportunities (e.g. Mayer, 1997:199); however, the evaluation scenes which determine them are generally not embedded within the classroom script. Instead, they occur outside the classroom as high-stakes comprehensive assessments such as the Staatsexamen. Thus, evaluation scenes and the behaviors associated with them do not assume high focus in the German classroom script.

Based on culture-specific differences in the structure of US and German universitylevel classroom scripts, German students are not socialized to orient to evaluation scenes within individual courses in the same way that Americans are. These differences in classroom socialization have meaning for the significance that Germans and Americans attach to the completion of Web Project II. The following comment by Anke and Catharina is particularly telling in this regard: "We worked over 4 hours on our excerpts, and dear Eric, we do not have class every day so we work on it on our spare time" [email \#16]. For these students, out-of-class work on Web Project II is not conceptualized as typical 'homework' associated with an evaluation scene as it is in the American classroom script, but rather as an extraneous activity that cuts into their free time.

Many American students hold an institutionalized script for foreign language teaching and learning that constitutes a specification of the general classroom script described above. In this more specific script, grammatical points comprise the primary transmittable facts and figures that must be received by students from the teacher in order for high-quality grades to be attained in evaluation scenes. Thus, Eric's course goals to "improve [his] speaking/reading/writing" [biographical survey] are thought to be achieved through an instructional method that "views grammatical competence as the essential feature of language ability" (Kinginger et al. 1999:853).

Researchers in foreign language education (e.g. Kern, 2000a; Tella, 1996:10) have noted the shifting shape of learner and teacher roles in NBLT. In the network-based foreign language classroom script, Shetzer and Warschauer (2000:177) argue that (1) there is a strong focus on collaboration in text construction; (2) critical evaluation during reading assumes high focus; and (3) an "interactive learning paradigm with an emphasis on autonomous learning" replaces a curricular learning paradigm with an emphasis on the transmission of objective facts (e.g. teacher-centered transmission of grammar points). This telecollaborative partnership with its emphasis on transatlantic collaborative essays, critical comparison of parallel texts, and partner correspondence on selfselected topics is prototypical of the network-based foreign language classroom script.

Some American students appear to have difficulties functioning as actors in the interactive learning paradigm prominent in telecollaboration. For example, Eric is resentful [email communication with the author, October, 2000] of his leadership role in the construction of Web Project I. Collaborative, learner-centered construction of a foreign language web site flouts his expectations to receive grammar instruction and thus, from his perspective, impedes his progress toward his course goals. Similarly, Don complains to the author that he doesn't really think he should be doing html in German class 
[personal communication, September, 2000]. Dylan, a 21-year-old student who is one of Don's partners in Web Project I, reports in a interview that Don repeatedly complains to him that "he's not learning anything in the course" and that he wishes the instructor would "give us vocabulary lists." These learner responses show that some students may experience irreconcilable dissonance between the foreign language classroom script into which they have been socialized and the new one associated with telecollaboration. These institutional constraints may, in turn, have meaning for language learning in telecollaboration.

\section{Summary and conclusion}

This sociocultural examination of German-American telecollaboration suggests several ways in which social and institutional aspects of the partnership may have meaning for language learning and use. First, the lower social and economic value of German as a Foreign Language in the US in comparison to EFL in Germany may contribute to a proficiency mismatch between German and American partners, if partnerships are established on the basis of age parity. In many cases, email message brevity, a result of lower proficiency levels, was interpreted pragmatically as a threat to positive face instead of economically or grammatically as the outcome of social or institutional features. Second, lack of internet access, cost of internet access, and limited hours of operation in computing labs contribute to the brevity of some Germans' correspondence. The best example is Annike who writes brief messages despite her enthusiasm for the course because of private internet access expenses accrued at an institution where computers are not readily available. Finally, socio-culturally shaped differences in the structure and epistemology of classroom scripts may have meaning for opportunities to receive assistance in L2 performance, the negotiation of meaning, and intercultural understanding. Because German students are typically not socialized to orient toward evaluation scenes such as Web Project II in individual courses, they may attach a different significance to it than Americans and subsequently may not participate in accordance with American expectations in its completion.

The use of social realist tenets as an explanatory tool for the social action of GermanAmerican telecollaboration has enabled a broadening of the analytic lens from microinteractional descriptions of online communication to include the meanings of societal and institutional dimensions of telecollaboration for aspects of electronically-mediated communication in telecollaboration. By attending to the social and institutional features of language valuation, technological know-how and access, and classroom scripts in conjunction with ethnographic data on individual learners' psycho-biographies and perceptions of situated activities in telecollaboration, I have emphasized the importance of the inter-relationship between structure and agency in interpreting human behavior in this learning environment. In this way, I have provided a socio-cultural description of NBLT. In my juxtaposition of virtual groups of differing functionality, I have shown that telecollaboration does not unproblematically afford target language interaction, opportunities for assisted L2 performance, negotiation of meaning, and intercultural awareness in all cases. Instead, we have seen that language learning is a complex and dynamic process in which learners always and everywhere exercise their socio-historically 
shaped agencies and do not necessarily act as innately programmed input processing devices.

\section{References}

Bernstein, R., Caplan, J. and Glover, E. (2000) America's most wired colleges. Yahoo Internet Life. http://www.zdnet.com/yil/content/college/college2000/college2000.html

Brown, P. and Levinson, S. C. (1987) Politeness: Some Universals in Language Usage. Cambridge and New York: Cambridge University Press.

Carter, B. and Sealey, A. (2000) Language, structure, and agency: What can realist social theory offer to sociolinguistics? Journal of Sociolinguistics, 4(1): 3-20.

Chapelle, C. (2000) Is network-based learning CALL? In: Warschauer, M. and Kern, R. (eds.), Network-based Language Teaching: Concepts and Practice. Cambridge and New York: Cambridge University Press, 204-228.

Cortazzi, M. and Jin, L. (1999) Bridges to learning: Metaphors of teaching, learning, and language. In: Cameron, L. and Low, G. (eds.), Researching and Applying Metaphor. Cambridge and New York: Cambridge University Press, 149-176.

Firth, A. and Wagner, J. (1997) On discourse, communication and (some) fundamental concepts in FLA research. The Modern Language Journal, 81, 285-300.

Gee, J. (1999) An Introduction to Discourse Analysis: Theory and Method. London: Routledge.

Good, C. (1977) Some structural aspects of casual conversation. UEA Papers in Linguistics, 4: $18-37$.

Hall, E. T. and Hall, M. R. (1990) Understanding Cultural Differences. Yarmouth, ME: Intercultural Press.

Hatch, E. (1992) Discourse and Language Education. Cambridge and New York: Cambridge University Press.

Härtling, P. (1997) Ben liebt Anna (2nd ed.). Weinheim und Basel: Beltz Verlag.

Herzog, R. (1997) Freiheit ist anstrengend: Fördern und Fordern. Frankfurter Allgemeine Zeitung. 6 November: 9.

Hilgendorf, S. (1996) The impact of English in Germany. English Today, 12(3): 3-14.

Jarvenpaa, S. L., Knoll, K. and Leidner, D. L. (1998) Is anybody out there? Antecedents of trust in global virtual teams. Journal of MIS, 14: 29-38.

Kerlin, J. (2001) Director, Education Outreach, Center for Education Technology Services, Pennsylvania State University. Email and phone correspondence, January and February 2001.

Kern, R. (1995) Restructuring classroom interaction with networked computers: Effects on quantity and characteristics of language production. The Modern Language Journal, 79(4): 457-476.

Kern, R. (2000) Literacy and Language Teaching. Oxford: Oxford University Press.

Kern, R. and Warschauer, M. (2000) Theory and practice of network-based language teaching. In: Warschauer, M. and Kern, R. (eds.), Network-Based Language Teaching: Concepts and Practice. Cambridge and New York: Cambridge University Press, 1-19.

Kinginger, C., Gourvés-Hayward, A. and Simpson, V. (1999) A tele-collaborative course on French-American intercultural communication. French Review, 72(5): 853-866.

Klobas, J. and Haddow, G. (2000) International computer-supported collaborative teamwork in business education: A case study and evaluation. International Journal of Educational Technology, 2(1). http://www.outreach.uiuc.edu/ijet/v2n1/klobas/index.html

Kramsch, C. and Thorne, S. (to appear) Foreign language learning as global communicative practice. In: Block, D. and Cameron, D. (eds.), Language Learning and Teaching in the Age of Globalization. London: Routledge.

Lantolf, J. P. (ed.) (2000) Sociocultural Theory and Second Language Learning. Oxford: Oxford University Press. 
Layder, D. (1993) New Strategies in Social Research. Cambridge: Polity Press.

Mayer, E. (1997) Whom do German universities serve? In: Ash, M. (ed.), German Universities Past and Future: Crisis or Renewal? Providence and Oxford: Berghahn Books, 191-205.

McGroarty, M. (1998) Constructive and constructivist challenges for applied linguistics. Language Learning, 48(4): 591-622.

National Center for Education Statistics. http://nces.ed.gov/

National Telecommunications and Information Administration. http://www.ntia.doc.gov/

Norton, B. (2000) Identity and Language Learning: Gender, Ethnicity, and Educational Change. London: Longman.

Pavlenko, A. and Lantolf, J. P. (2000) Second language learning as participation and the (re)construction of selves. In: Lantolf, J. P. (ed.), Sociocultural Theory and Second Language Learning. Oxford: Oxford University Press, 155-177.

Reddy, M. (1993) The conduit metaphor. In: Ortony, A. (ed.), Metaphor and Thought. Cambridge and New York: Cambridge University Press, 164-201.

Reichert, M. (2000) Der Weg zur Zweitsprache ist weit. die tageszeitung. 5 February: 33.

Sacks, H., Schegloff, E. and Jefferson, G. (1974) A simplest systematics for the organization of turn-taking for conversation. Language, 50(4): 696-735.

Schank, R. and Abelson, R. (1977) Scripts, Plans, Goals and Understandings. Hillsdale, NJ: Lawrence Erlbaum.

Shetzer, H. and Warschauer, M. (2000) An electronic literacy approach to network-based language teaching. In: Warschauer, M. and Kern, R. (eds.), Network-Based Language Teaching: Concepts and Practice. Cambridge and New York: Cambridge University Press, 171-185.

Sproull, L. and Kiesler, S. (1991) Connections: New Ways of Working in the Networked Oranization. Cambridge, MA: MIT Press.

Statistisches Bundesamt. http://www.statistik-bund.de/

Tannen, D. (1981) The machine-gun question: An example of conversational style. Journal of Pragmatics, 5(5): 383-397.

Tella, S. (1996) Foreign languages and modern technology: Harmony or hell? In: Warschauer M. (ed.), Telecollaboration in Foreign Language Learning. Honolulu, HI: University of Hawai'i, Second Language Teaching and Curriculum Center, 3-18.

Warschauer, M. (1995) Virtual Connections. Honolulu, HI: University of Hawai'i, Second Language Teaching \& Curriculum Center.

Warschauer, M. (ed.) (1996a) Telecollaboration in Foreign Language Learning: Proceedings of the Hawai'i Symposium. Honolulu, HI: University of Hawai'i, Second Language Teaching \& Curriculum Center.

Warschauer, M. (1996b) Motivational aspects of using computers for writing and communication. In: Warschauer M. (ed.), Telecollaboration in Foreign Language Learning: Proceedings of the Hawai'i Symposium. Honolulu, HI: University of Hawai'i, Second Language Teaching \& Curriculum Center, 29-46.

Warschauer, M. (1998) Online learning in sociocultural context. Anthropology and Education Quarterly, 29(3): 68-88.

Warschauer, M. (2000) On-line learning in second language classrooms: An ethnographic study. In: Warschauer, M. and Kern, R. (eds.), Network-Based Language Teaching: Concepts and Practice. Cambridge and New York: Cambridge University Press, 41-58.

Warschauer, M. and Kern, R. (2000) Network-Based Language Teaching: Concepts and Practice. Cambridge and New York: Cambridge University Press.

Weber, W. M. (2000) Wir wollen viel Wow. Der Spiegel. 30 October: 246.

Woodson, J. (2000) If You Come Softly. New York: Penguin. 
Reproduced with permission of the copyright owner. Further reproduction prohibited without permission. 